\title{
humanidades
}

Revista humanidades

Enero-junio, 2016 • Volumen 6, número 1 • ISSN 2215-3934 • pp. 1-61

\section{La forma semiótica artística-textual de decir y hacer lo in(debido): La meningitis y su sombra de Horacio Quiroga}

DOI: http://dx.doi.org/10.15517/h.v6i1.25117

\section{Ricardo Vargas Durán}

Investigador de la Escuela de Estudios Generales de la Universidad de Costa Rica y profesor de Comunicación y Lenguaje de esa misma unidad académica.

Correo electrónico: ricardo.vargas@ucr.ac.cr

Todos los derechos reservados. Universidad de Costa Rica. Esta revista se encuentra licenciada con Creative Commons Reconocimiento-NoComercial-SinObraDerivada 3.0 Costa Rica. (CC BY-NC-SA 3.0 CR)

Correo electrónico: humanidades@ucr.ac.cr / Sitio web: http://revistas.ucr.ac.cr/index.php/humanidades 


\title{
La forma semiótica artística-textual de decir y hacer lo in(debido): $L a$ meningitis y su sombra de Horacio Quiroga
}

\section{Resumen}

Se aplica con toda intensión teórica y metodológica para la lectura interpretativa del cuento de Horacio Quiroga, la semiótica sociológica y el reconocimiento de los diferentes mensajes que se estructuran en el sistema "multimodal del texto", como referencialidad discursiva que enmascara otros razonamientos en la producción artístico literaria de lo narrado, es decir, más allá de la estilización propia de una literatura que usa lo extraño, lo raro y lo sorpresivo, como realidades que explican las relaciones sociales entre clases en vías de cambio y clases emergentes.
Palabras clave: Semiótica social, Horacio Quiroga, La meningitis y su sombra.

\section{An Artistic and Textual Way to Say and Do What is in(proper): $L a$ meningitis y su sombra by Horacio Quiroga}

\begin{abstract}
The sociological Semiotics and the recognition of the different messages that are framed in the "multimodal" system of the text are theoretically and methodologically applied to the interpretative reading of Horacio Quiroga's short story. This is discursive reference that masks other lines of reasoning in the literary and artistic production of what is being narrated, going beyond the own stylization of a literature that uses "the strange", "the weird" and "the surprising" as realities that explain the social relationships between the changing and emerging classes.
\end{abstract}

Keywords: Social

semiotics, Horacio Quiroga, La meningitis y su sombra. 
Al Doctor Roberto Castillo Rojas

Maestro sabio; erudito y gran ser humano

La producción literaria del escritor uruguayo Horacio Quiroga (18781937) ha sido de notable interés en muchos estudios que oscilan dentro de las perspectivas tradicionales hasta las más actualizadas, esto según es el modelo de interpretación literaria de mayor importancia en el lugar y en el tiempo en que se haya producido. ${ }^{1}$

Particularmente he seleccionado otra teoría y metodología para este trabajo de lectura interpretativa y que a mi entender, abre otra posibilidad en el campo de las investigaciones literarias que se han dedicado a este autor tan complejo, precisión que implica de hecho, que las demostraciones asuman una doble perspectiva derivada de la semiótica, específicamente la que proponen los investigadores Iourij Lotman y Theo van Dijk ${ }^{2}$, el primero por su aporte a la semiótica, pero la que implica la táctica de desciframiento de lo sociológico en el texto, es decir, con qué recursos literarios, el autor remite al lector al ámbito social constituida por las relaciones entre las clases sociales, sus variaciones, inestabilidades, descripciones, etc. Y a van Dijk y otros, por la sistematización de sentidos organizados por el sistema "multimodal"; ambas consideraciones y delimitaciones ciertamente novedosas y que a continuación me referiré grosso modo. 
En realidad Lotman marca la historia de la semiología con aportes innovadores para la articulación de la semiótica y que sin duda alguna, dado el ingenio de sus enfoques y tratamientos del sentido, la hacen más rica en perspectivas para otra lectura y en consecuencia, para otra interpretación de los modelos o estructuras en los que se acomoda el sentido del mundo, el de los objetos, el de los hombres y las mujeres que proveen la sociedad humana, los avatares históricos del pensamiento como comprensión de eso que conocemos como la realidad ${ }^{3}$ del entorno histórico y cultural.

Ciertamente el campo de interpretación artística que asume esta nueva disciplina en particular, se deslinda con muchas propiedades alternativas de los lingüismos con los que se conecta la semiótica tradicional, allende esta, a los amplios panoramas que presentan los problemas lingüísticos; este afán de Lotman permite que su propuesta teórico-metodológica, se relacione con otras disciplinas más cercanas a descifrar el mundo y la realidad humana, la cultura y la sociedad, mediatizada a través de sus prácticas materiales de la formulación y el uso del sentido; específicamente voy a utilizar la que interna en algo tan importante como es la latencia de la comunicación social como terminología.

Pero la terminología empleada por la comunicación, Lotman la considera de facto que reduce y simplifica algo que es más complejo y tan dinámico como lo que se evidencia en mayor grado de complejidad en el seno de los grupos humanos socialmente organizados e históricamente productores de sentido, como todo en lo que estriba la cultura de los pueblos. Hay inquietudes antropológicas que no se pueden omitir dentro del espectro que es el conocimiento de los recursos con los que contamos como especie hablante y creadora de signos múltiples.

\section{Aspectos teóricos de Iourij Lotman}


En ese sentido, es menester para Lotman el cambio de varias categorías utilizadas por la teoría tradicional de la comunicación. Por ejemplo, la comprensión de las nociones "emisor” y "receptor", útiles para explicar el diálogo o la interconexión entre dos sujetos hablantes. El cambio lo sugiere en consecuencia que se use el de "transmisor" y "destinatario", lo que supone, la concepción y el uso de las herramientas que otorgan los distintos lenguajes, las tecnologías para la información, y otra postura para el investigador literario y que nos remite también, a concepciones y usos variados de todos los recursos activos implicados en ello, pues a la postre y según mí interés, se podrán verificar los cambios de las mentalidades que a través de la historia cultural de occidente, re-direccionan todo lo humano como quehacer del intercambio social.

El mundo ideológico elaborado como concepción estática, clasificable e invariable, coincide con la creación de aparatos simbólicos estamentarios, donde el artículo del sentido será siempre privilegio de las instituciones que hayan obtenido a su vez, mayor cuota de poder en cuanto a las definiciones, el valor reproductor de ello siempre y en contra de cualquier variación de lo mismo, al punto de ser siempre recalcitrantes, autoritarias y unívocas. Por el contrario, el signo, es generador de novedades insospechadas e insólitas, no es nunca pasivo como el que propicia necesariamente para abastecerse de poder, insisto, una sociedad organizada, constituida por oyentes únicamente receptivos, es decir, los receptores.

Otro de los alcances o limitantes que supone la comunicación es que el concepto receptor, carece de todo horizonte comunicativo, probablemente porque el nivel en que se le ubica al receptor, solo es algo muy primario, 
muy básico en la real esfera de lo que es comunicarse con y a través de; este pasivo rol de subordinación, intenta siempre solo reproducir, nunca innovar, desde luego porque esa posibilidad es inexistente, solo podrá actuar el que emite sin encontrarse con el otro como uno que posee las mismas facultades y los mismos derechos de la emisión. La palabra del emisor sustituye y anula en casos extremos la propia del otro emisor potencial, pues este no existe, únicamente ocupa un lugar en el espacio. Desaparece entonces el horizonte del diálogo, no solo con el inmediato, metáfora del lugar y del tiempo, sino también con otro que trasciende estos límites internos pues las sociedades son hechos humanos que se suceden y se inter relacionan con otras comunidades productoras de sentido.

Si aceptamos (...) la tesis de que el lenguaje es una forma de comunicación entre dos individuos, deberemos hacer algunas precisiones. Será más cómodo sustituir el concepto de "individuo" por lo de "transmisor del mensaje" (remitente) y "receptor del mensaje" (destinatario) (p. 19).

Todo proceso de comunicación es algo conscientemente acordado dentro del seno mismo de los signos históricos, sociales y de hecho culturales. Lo artístico en sus diversas y múltiples manifestaciones también le pertenecen irrevocablemente. Pensemos por un momento en todos y cada uno de los géneros artísticos, en este caso el cuento como literatura también genérica, ¿podría desligarse este del contexto donde coinciden dialógicamente tramados el remitente y el destinatario? A mi entender, y en los términos que expresa Lotman, sería deficiente y limitaría en consecuencia el campo de lectura, de comprensión, de penetración en las estructuras mentales de la comunidad histórica y social, de ella entre los suyos, de esta con los del horizonte en que la dicción artística se subleva y se resiste a morir con el 


\section{La forma semiótica artística-textual de decir y hacer lo in[debido]...}

grupo contextual; esta se orienta también con sus proyecciones meta históricas.

Lo contundente es que hoy podemos leer la escritura de ayer, las estilizaciones que constituyen la materia de los géneros literarios y que no se restringen por las clasificaciones como tales, es decir como géneros, subgéneros entre otras, ni tampoco como semantizaciones que han obtenido valores de carácter cualitativo entre sus propios congéneres, quienes tienen su manera propia de concebirse, de verse en el espejo de lo social, que deviene complejas estructuras en virtud de las relaciones entre diversos grupos, las clases sociales, todas y cada una productoras de la palabra que enuncia un lugar de mayor o menor importancia, esto, según sea el modelo sociológico imperante.

El pensamiento del escritor se realiza en una estructura artística determinada de la cual es inseparable (...) Tolstoi expresó de una manera extraordinariamente gráfica la idea de que el pensamiento artístico se realiza a través de la "concatenación" -la estructura- y no existe sin ésta, que la idea del artista se realiza en su modelo de la realidad (p. 22).

Otro aspecto de suma importancia estriba en el hecho de que todo escritor al seleccionar un modelo genérico de escritura, como en el caso de Quiroga que ha escogido el cuento, queda por defecto circunscrito a un modelo estructural que hace que su narración sea lo que ha seleccionado y no algo diferente. En este sentido que supone una obviedad y sin que deje de expresar de mi parte un cierto desacuerdo con lo dicho, el asunto es que la mayoría de los que se han involucrado con el escritor y por ende con la forma de la escritura, lo consideran como un narrador que utiliza asuntos 
que describen un ámbito de variaciones de algo difícil de precisar, raro, extraño y ligeramente fantástico. Quizá por eso, la lectura de Quiroga puede distraer al lector de época y al lector actual por unas rutas laberínticas del sentido que devienen disyunciones más complejas que la trama misma condicionada por las reglas del género específico. Yo pienso entonces al respecto, en la urgencia de abastecer la lectura más con lo implícito que con lo explícito, o sea, con los asuntos de la dicción y de la narración que están más del lado de lo que no se dice, aunque se le sugiera al lector conocedor de otros lenguajes vedados. Afirma Lotman:

La elección, por parte del escritor, de un determinado género, estilo o tendencia artística supone asimismo una elección del lenguaje en el que piensa hablar con el lector. Este lenguaje forma parte de una compleja jerarquía dada, de un pueblo dado o de una humanidad dada...La lengua como artículo, modeliza no solo una determinada estructura del mundo, sino también el punto de vista del observador (pp. 30-31).

Agregaría consecuentemente que debe aceptarse en principio y como tal, que existe la consecución lógica, es decir artística de parte del lector que representa otra comunidad interpretativa en que las observaciones o el sistema de representaciones del escritor en el modelo de escritura seleccionado por este, contiene y revierte ambos mundos de interpretantes dinámicos, coadyuvados en un mismo afán dialógico por develar.

Por último, para concluir esta parte me interesa la tesis que sostiene Lotman cuando usa la categoría "capacidad" en su texto, para referirse a los distintos instrumentos de los que se vale un estratega destinatario para decodificar datos que si bien están en la superficie sensible de la narración, 


\section{La forma semiótica artística-textual de decir y hacer lo in[debido]...}

obligan metodológicamente hablando, a evidenciar y sistematizar los idearios que específicamente hacen a un grupo humano histórico con su forma particular dada, ya sea por lo estrictamente endógeno (cultura interna) o exógeno (cultura externa). Por ello, toda lectura viene a ser simultáneamente otra re-lectura interpretativa, lo que para Lotman equivale sin menoscabo metodológico alguno, a una "segunda lectura".

Al poseer la capacidad de concentrar una enorme información en la "superficie" de un pequeño texto...el texto artístico posee otra peculiaridad: ofrece a diferentes lectores distinta información, a cada uno a la medida de su capacidad; ofrece igualmente al lector un lenguaje que le permite asimilar una nueva porción de datos en una segunda lectura. Se comporta como un organismo vivo que se encuentra en relación inversa con el lector y que enseña a éste (p. $36) .^{5}$

Esto daría pie para que pensemos en que la aludida dinámica lecturarelectura intervenga con mayor amplitud en el procedimiento para descifrar o decodificar los sentidos que no están simplemente ahí colocados, en las narraciones como lugar o espacio sensible, como podría darse también en el caso de la pintura, que la observamos con la misma mirada con la que vamos leyendo las entreveradas líneas y colores, las luces y las sombras, las representaciones que tejen como en la literatura, provocadoras narraciones donde suceden las situaciones que solo pueden sustentarse sobre la referencia de lo que percibimos como realidad y en sumo grado, la realidad, la propia y la ajena, la circunstancial o la que indistintamente documentan las producciones artísticas, sean estas como he sugerido, visuales o táctiles; improntas sobre superficies de tela o de papel como soportes sustentables. 
Todas la transmisión de hechos, se imprimen con su impronta propia sobre soportes, diversos, sea cual sea la técnica que se utilice para realizar la belleza disyuntiva como las que encierran las vertiginosas narraciones de Quiroga; a cada una le corresponde su propia ensoñación que se adscribe a la tradición de literatura fantástica, para dar un tono de ocultamiento, propio de sectores sociales por igual imprecisos y hasta absurdos, plenos de lenguajes cuyas codificaciones nos remiten más propiamente a la gran e innoble metáfora del laberinto, donde se duda con la certeza de lo impreciso y a todo pesar, se distingue la ruta.

Otro caso de interés: la relación entre lo casual y lo sistemático en el texto artístico posee distinto significado para el transmisor y para el receptor. Al recibir un mensaje artístico, para cuyo texto debe aún elaborar el código para descifrarlo, el receptor construye un determinado modelo ${ }^{6}(\ldots)$. De este modo, al pasar del emisor al receptor, puede aumentar el número de elementos estructurales significativos. Es éste uno de los aspectos de un fenómeno complejo y hasta ahora poco estudiado como es la capacidad del texto artístico para acumular información (pp. 38-39).

Se me hace imprescindible en este apartado, empezar recurriendo a Mijail Bajtín, pese a que este trabajo de selección en el estricto sentido, no sugiera al mismo. Digo entonces que este autor logra un entronque interesante

La semiótica discursiva o social de Van Dijk entre los autores porque el filósofo ruso, de notable importancia para la semiótica moderna y tremendamente actual, es en cierto modo punto de referencia y se encontrará sugerido por Lotman y Van Dijk, el primero en cuanto a las categorías de uso y la articulación de estas; el segundo porque en el mismo trabajo colegiado, se hace la alusión explícita de Bajtín para 
concretizar el método por excelencia de la Semiótica Discursiva, a saber: las construcciones del sentido multimodal.

La reflexión que hace el teórico ruso a partir de demostraciones dialógicas y polifónicas en la escritura de ciertos géneros literarios, se vincula a lo que él llama fuerzas internas, centrípetas y centrífugas del sentido. En ellas se podrá demostrar la participación de los diferentes sectores humanos definiendo y redefiniendo el lugar centro en que se concentra el sentido racional al que se obligan a obtener los seres humanos, así como todas las mediaciones de poder correspondiente a todos los ámbitos posibles y de acuerdo al principio de organismo social. La palabra por ejemplo constituye la lengua y el lenguaje, dispone de su definición institucional y segrega otras formas que no corresponden al "sentido común" con el que las clases superiores, dotan de poder no solo al hablante, sino que lo revisten de otros lenguajes que apuntan en su conjunto a la totalidad, es decir, a la verdad y a lo verdadero como su consecuencia.

De ahí entonces que el conector sugerido arriba entre los autores, sea el que se comprende como "logocentrismo", como la fuerza del sentido organizador y dominante que también consta en la definición dada por las preceptivas artísticas tan abundantes a lo largo del desarrollo de las teorías de la estética en general. Así, el texto de la escritura o la escritura como inter texto, consiste en estilizaciones, pienso metafóricas, que reúnen lo que se podría entender como una arenga histórico-cultural y que ha dado como resultado, la diversidad de los llamados géneros literarios, de los cuales y a todas luces del ruso Bajtín, materializan estas fuerzas de lucha interna entre quienes le dan un sentido mono lógico y mono estilístico a un fenómeno diverso, rico, múltiple pues ni el habla ni la escritura, es un 
particular beneplácito para unos pocos, aunque ya sabemos, que a través de la historia, ciertos sectores académicos, hayan secuestrado lo diverso para reducirlo a lo único; el canon como expresión única en que se encierra la idea de lo bello, excluyendo todo lo que no se le adapte a sus términos de racional exactitud.

Por eso, las relaciones múltiples entre géneros de literatura rompen con ciertas fronteras normativas bastante débiles, como en este caso, entre el cuento y la novela, que comparten estructuras del sentido tanto más, tanto menos, de acuerdo a la extensión pues lo que realmente observo, son las referencias al mundo real, en este caso y aunque suene arbitrario, al socio texto, a las mentalidades propias e intrínsecas de las clases que se definen per se, cobrando vida y ocupando un lugar en el espacio narrativo. De esta manera se afirma en el texto guiado por Van Dijk lo que sigue:

En el nuevo paisaje, no solo la lengua escrita está menos en el centro...el cambio está produciendo textos que son fuertemente multimodales. Es decir, los productores de textos hacen uso cada vez más mayor (sic) y más deliberados de una gama de modos de representación y comunicación que coexisten dentro del texto dado (p. 374).

El asunto a mí entender faculta la complejidad de abordaje en los procedimientos de lectura que no pueden reducirse a un solo modelo, ni tampoco explicar la estructura literaria solo considerando las características propias que hacen de esa escritura, un modelo que se ajusta a lo que establece como válido. De hecho, pienso que se ha perdido un tiempo de mayor disposición en tanto y en cuanto la institución de la 
lengua, ha hecho el ejercicio hegemónico por caracterizarla, más aún, reducirla al único modelo regente.

Una consecuencia de este cambio es que se hizo imposible interpretar en forma cabal los textos prestando atención exclusivamente a la lengua escrita: esta existe como un elemento representativo en un texto que siempre es multimodal y que debe leerse en conjunción con todos los otros modos semióticos de este texto (p. 374).

En consecuencia, lo sugerido y lo que selecciono es otra manera no tradicional de leer a Quiroga desde estas relaciones en las que se confrontan las fuerzas que de hecho existen en el contexto social constituido por diversas y singulares representaciones de la realidad y que según el autor, abre el círculo para develar hechos no solo de personajes, sino de profundas transformaciones mentales que pueden perfectamente relacionarse con la noción de "modernidad", es decir, otras formas de concebir y entender los cambios que se realizan al interior de una sociedad que expresa con todo rigor, la lucha entre los viejos modelos sociales que aún sobreviven y que se niegan a la transformación del modelo, en este caso, el "pequeño burgués", estamento sin duda alguna dominante y confrontado con el de las castas aristocráticas que para el siglo XX poca importancia representan, pues han perdido el acicate simbólico y, sobre todo, el modo económico que sostenía sus desmedidos privilegios.

Probablemente una entre otras, de las principales atribuciones de estos desmedidos privilegios, consiste en el acceso a la educación como promoción social del rango y a todas las extensiones que ello significa para 
los modelos de grupos elitistas históricos y tradicionales. La ruptura que conlleva los modelos educativos concebidos como un derecho humano para todos los ciudadanos, revoluciona el mundo occidental, pues le otorga legítimas herramientas de promoción social a los sectores tradicionalmente excluidos. Por eso es importante el proyecto liberal educativo de la modernidad Latinoamericana que extendió la escuela de los centros principales secularizándola y adaptándola a los lugares por donde se difunde, en especial, la enseñanza que faculta a los niños a tener acceso a la escritura por la lectura apropiada de los signos, superando el analfabetismo dominante aún vigente en muchos países realmente pobres, aunque ricos en su diversidad lingüística y potencialmente productores de géneros narrativos propios de la cultura de los hablantes, carentes de escritura. Esto modifica a pesar de la limitación aludida, el paisaje socioartístico que abastece, con materia prima precedente de otros inter locutores con un rico aporte potencial que se transformará en muchas y diversas literaturas. ${ }^{7}$

Uno de los análisis de los principales modos de representación en virtud de los cuales un determinado texto se realiza y produce. El segundo consiste en un intento de comprender el potencial de origen cultural e histórico para producir significado de cualquier modo semiótico individual (p. 374).

Téngase en cuenta que mucha de las tradiciones orales que circularon entre los pueblos Latinoamericanos, nutrieron la imaginación de las leyendas autóctonas que se mezclaron con las de los europeos y africanos, dando como resultado, un mestizaje narrativo rico en imágenes, seres fantásticos y situaciones de tensión por el extrañamiento que crea la interacción misma en los oyentes. Estas pasan de generación a generación y circulan por todos los territorios amerindios, re-elaborándose muchas de estas a través de un 


\section{La forma semiótica artística-textual de decir y hacer lo in[debido]...}

lento proceso de conocimiento, uso y narración. Muchos de nuestros cuentistas, adaptándose a la moda de estilización vigente, toman estos materiales y le dan enfoques distintos que no pierden como es el caso del extraordinario escritor Miguel Ángel Asturias y Alejo Carpentier, sus antecedentes con el texto fundador, el cual que no se invalida y que probablemente se sumerge en las mentalidades de grupos humanos que están bastante atrás.

En ese sentido es que aparecen los contornos o el perfil que pauta con toda efectividad hacer un uso apropiado de los postulados que pueden intervenir en el procedimiento de lectura requerido, abordando por decirlo de alguna manera, algunos de los pre sentidos utilizados y que componen estructuralmente el cuento seleccionado de Quiroga. La actividad obliga a descomponerlos, a desmantelarlos, y a organizarlos pues eventualmente, proporcionan más información sucinta que la que se daría si únicamente, nos valemos de los pormenores que saltan a la vista con el ejercicio de la simple lectura, es decir, aquella que carece del referente histórico y de su construcción mental, del contexto en el espacio social en que las fuerzas del signo se atraen o pugnan por ocupar un lugar de dicción, como sucede con el enunciado y el discurso que patentiza las inquietudes con tales relaciones humanas.

Nuestro interés está en la textualidad, en los orígenes sociales y en la producción del texto tanto como su lectura. Designamos a esta práctica semiótica social [cursivas añadidas] para llamar la atención sobre todas las formas de significación como actividad social enmarcada en el campo de la política, de las estructuras de poder y, por tanto, sometida a las disputas que surgen debido a los distintos intereses de los que producen textos (p. 375). 
-No vuelvo de mi sorpresa. ¿Qué diablos quiere decir la carta de Funes, y luego la charla del médico? Confieso no entender una palabra de todo esto.

He aquí las cosas. Hace cuatro horas, a las siete de la mañana, recibo una tarjeta de Funes, que dice así:

Estimado amigo:

Si no tiene inconveniente, le ruego que pase esta noche por casa. Si tengo tiempo iré a verlo antes. Muy suyo.

Luis María Funes (p. 105). ${ }^{8}$

En la narración del cuento, la categoría efectista de la "sombra", incluida como elemento en la articulación en el título, previene al lector de la presencia de un suceso implicado en la trama. Se trata de una especie de pesadilla que sufre una noche el ingeniero Carlos Durán, personaje destacado entre otros más, pues a este, le toca en suerte, según piensa el médico Ayestarain, que la señorita María Elvira Funes, ponga en él un especial interés, evidentemente amoroso, pero también truculento.

La tensión utilizada en los términos que Quiroga usa para entretener al lector, procede de la recurrencia a "lo raro, lo extraño, lo inverosímil", categorías que desde luego proyectan el cuento desde las estilizaciones acordes con aquella literatura tan extensa, que se vale de asuntos reales no fácilmente explicables o comprensibles con los razonamientos más verosímiles como tradicionales. La situación le podría suceder a cualquier persona, pero no precisamente con esa generalización, pues la señorita María Elvira, pertenece a una clase pequeño burguesa, resistente a considerar dentro del círculo social en que ella vive, la posibilidad de que 
se enamore y hasta que se case con cualquier hombre soltero, este requerirá de algo más exigido por la condición social de la señorita.

Como toda mujer que se estime como tal, rica y con apellido, su vida transcurre entre las labores propias del hogar, aquel que es destinado a las señoritas de la localidad como clase alta y distinguida. Por eso a ella se le construye a partir de las antiguas asignaciones del patriarcado, designio de toda mujer. María Elvira aporta cualidades femeninas como son la de mujer primorosa, coqueta e histriónica en público, aniñada y juguetona en asuntos de su incumbencia, fría y calculadora, caprichosa y sobre todo enigmática, en tanto y en cuanto que realiza la estrategia de hacer sugerir, pero también negar cuando se le confronta.

La casa de los Funes, lugar instituido por un padre que ha muerto y por una madre viuda y dedicada a las labores hogareñas, la rige con toda autoridad masculina Luis María Funes, el varón único y el mayor de toda la casa. Él gobierna la vida de las tres mujeres, porque además de las ya mencionadas, consta otra hermana menor llamada Angélica y cuya presencia en la trama, se encuentra mayormente menguada que la de María Elvira y su Hermano Luis.

Al morir el padre, Luis asume el rol de transposición de todas las prerrogativas que obtienen los hombres pertenecientes a la pequeña burguesía, sobre todo, el de superioridad, racionalidad, inteligencia y algo de astucia para defender el círculo social que él administra según dictan las normas sociales, la clase y la imagen de obligada decencia. Además, mantiene la vigilancia sobre el grupo de mujeres, pues e estas, en la tradición patriarcal, se les debe cuidar de todo ataque externo por ser ellas 
como la Eva bíblica, ingenuas, volubles y en último caso, más sentimentales y frágiles, que racionales y fuertes.

Tanto el doctor Ayestarain como el ingeniero Carlos Durán, pertenecen a otra clase social más de tipo emergente. Aunque no tengamos ningún antecedente familiar de estos dos varones, el haber tenido acceso a la educación y atribuirse un título profesional, les otorga en relación a otras clases que ni se mencionan, una distinción particular, máxime si tenemos en cuenta que, el acceso al estudio en una sociedad de principios del siglo $\mathrm{XX}$, facilitó a muchos jóvenes a disfrutar de una cierta movilidad social ascendente. Doctor e Ingeniero, son títulos acreedores de distinción. El pormenor que los condiciona, es que ambos, no tienen la distinción que procede de una familia de tradición burguesa como son los miembros de la familia reputada de los Funes.

En ese sentido, ambicionar una relación con fines matrimoniales con alguna de las Funes, constituye una verdadera pérdida de tiempo. Pero se da, María Elvira conoce al ingeniero Carlos Durán en una que va y viene, y para el narrador, ese ha sido en único instante en que dos sectores tan diferentes pueden tener algún contacto. En el caso del doctor, la relación con los Funes es aún más frecuente, pues el título y cierta amistad con el patriarca de la familia, le da una concesión que no es ni siquiera pensada por el ingeniero.

Pero sucede algo extraño, María Elvira se enferma. Primero se cree por los síntomas manifestados de que se trata de la terrible meningitis, enfermedad que ciertamente si la leemos, revela la sombra de la muerte como metáfora de un mal sin remedio que trae la desgracia a toda la familia, pero en particular sufrimiento a la afectada, luego, se desecha esta idea y es cuando 
la enfermedad provoca toda una serie de situaciones y definiciones, difíciles de entender para el ámbito familiar, para el médico, y sobre todo para el ingeniero Carlos Durán. Todas las noches, a una hora exacta, María Elvira cae en cama con temperaturas altísimas y delira, y en sus delirios pide que le llamen al ingeniero Carlos Durán.

Sin duda, las situaciones que produce la enfermedad crónica de la señorita, le permite a Carlos Durán el acceso al seno de la Familia Funes, lo que implica, algo totalmente inesperado por no haber lazo alguno entre él y la familia. Entonces se recurre a la estrategia enunciadora de los límites y los alcances con los que este asunto, realmente desprovisto de alguna lógica racional, obedezca a los términos implicados en cierto contrato social dado entre ambos caballeros; que delimite las verdaderas razones por las cuales se le da licencia de acceso a la casa de la familia, pero también, y esto rompe con las normas de la privacidad y en cierto modo del recato, al lecho de la enferma, a quien el ingeniero consuela con su presencia, la observa y él es observado y hasta llega a tomarla de la mano, mientras escucha las palabras explícitamente seductoras que ella le expresa al ingeniero delante del círculo familiar y el médico que atiende profesionalmente el caso.

Queda así documentado en la trama, la tensión erótica que significa aquella enfermedad y que, a ciencia cierta, no puede explicarse con los recursos del conocimiento médico y que se presta a su vez, para hacer distintas lecturas, pues además de que se pueda leer como una estrategia desarrollada por una mujer subordinada a los prejuicios de clase, y a la dominación del sistema patriarcal reproducido cabalmente por su hermano Luis, se plantea también, una disyunción igualmente anómala, pues en otros momentos de la narración, en la que María Elvira goza de salud física, 
se niega a perpetuar con los indicios y las sugerencias de amor y deseo hacia el ingeniero Durán, más aún, lo trata con desenfado y evita a todo trance, evocar las promesas de amor que hiciera en su lecho de enferma.

Carlos Durán se ve obligado y hasta sometido a los caprichos enfermizos de María Elvira. Marcado por una especie de ingenuidad, atributo dado por el narrador, este se va enamorando cada vez más y más de ella, quien procede hábilmente a ocultar y negar sentimientos que le den esperanza de respuesta formal. Así, el ingeniero sufre de continuas angustias y aunque el doctor le hace ver, lo maravilloso que es que la Funes le haya concedido tal condescendencia de amor inmerecido, en realidad lo que le genera es sufrimiento y dolor extremo, al punto que siente la necesidad de huir, viajando lejos a otros países.

Sin embargo, como suele suceder en la relación doble de aceptación/desprecio, el ingeniero antes de partir, decide ir a despedirse de la Funes, la cual lo recibe con desgano, porque ella misma refleja síntomas de enfermedad depresiva, pero se resiste como lo ha hecho en otras oportunidades, a ceder a las demandas del infortunado varón. El diálogo entre ambos, pasa de lo meramente formal del trato consabido a una auténtica explosión de pasiones y arrebato de parte del ingeniero. La carga erótica insatisfecha colma los límites psicológicos que un ser humano puede soportar, sobre todo si se tiene en cuenta, que María Elvira nuevamente, manifiesta a través de sus actitudes no verbales, indiferencia.

El patriarcalismo se derrumba en un acto desesperado ante la mirada fría de María Elvira, quien ve como el lector del cuento, cómo se rompen en privado los límites de fuerza o resistencia al dolor, algo contrario al signo de la masculinidad y que se le impone en el proceso educativo y 
circunstancial, a todo varón, heterosexual compulsivo. Él llega al llanto, se descompensa, grita arrebatado por un momento de locura su amor por ella y expresa todo el sufrimiento y el dolor de eso tan extraño que siente y lo tortura, difícil de entender dentro de cierta lógica que se desliga del sentimentalismo vulgar.

Finalmente, en dicho intersticio narrativo, la mujer baja el nivel de su resistencia teatral y como él, confiesa también su amor y ambos se abrazan recordando la promesa que una vez le hiciera a ella en el lecho de enferma rara como desprovista de todo recato delante de su familia nuclear. Por supuesto, la iniciativa de ambos, se verá coronada como el cumplimiento de las expectativas más tradicionales e institucionalizadas: se casan. Lo sabemos a partir del uso de un recurso literario post scriptum, artificio bastante frecuente en la estilización literaria de las vanguardias, tan evidentemente simpáticas e ingeniosas, pues aplican recursos para dirigir el sentido, por otro vector que produce una sensación de rareza en el lector lineal. Se trata de la transgredir el ordenamiento unívoco al introducir otro texto anacrónico, pues como se verá, no coincide ni con el tiempo ni el lugar de enunciación. Es una trama que indica la transposición de tiempos, pues el intersticio mencionado, hace que, el texto narrado, no solo sea lectura de lo pasado, sino que confirma que lo descrito está siendo la documentación de un hecho que puede ser tanto más o tanto menos coincidente con el cuento.

María Elvira, observa sobre el hombro del escritor, al cual suponemos es Carlos Durán, su actual esposo, la escritura del cuento hecha como narrador de La meningitis y su sombra. Nuevamente, la metáfora "sombra" remite a otras extensiones del sentido como son amparo, protección ante 
cualquier peligro externo, abrigo o cobijo, ligado a casa u hogar paterno, contrariamente también a algo siniestro; apunta a conferirle a esa mujer en particular un rol inapropiado, pues ella misma expresa no estar de acuerdo con el final cuando se abrazan y que consta en el cuento.

En otro sentido, afirmo que en lo que respecta a tensión erótica entre el ingeniero y la señorita, correspondería a una forma de metáfora o tropo de la tensión social entre individuos que la representan, es decir, hay que hacer notar la "inmanencia” semiótica. Más allá del amor como asunto predilecto por el Romanticismo tardío al que correspondería el cuento, la inversión social se realiza al mezclarse entidades que se suponen, están variando el paisaje social de época. Se trata entonces de la noción de un nuevo ser, una nueva humanidad, sin intenciones ciertamente idealistas en esta mi lectura que propone más bien la crisis que representa para las clases adineradas, rebajarse por otros méritos extraños, a la nueva condición sociológica.

Ciertamente la no realización de los deseos amorosos para llamarlos de alguna manera a los eróticos reproductivos, le conceden probablemente a ambos personajes, fuertes dosis de dolor mortal, pero hay que tener en cuenta, que tales manifestaciones de la psiche, no están de ninguna manera desprovistas de que se le entienda como un metalenguaje que nos remite a eso otro que son las movilidades sociales, es decir, también en el tenso hecho de pertenecer para ser, a un espacio ajeno con mayores satisfacciones placenteras y beneficios económicos. Por ello, la revolución sexual corresponde en este cuento, igualmente a otra revolución de tipo sociológica. Las palabras que se emplean son las claves para entender varios sociolectos que hay que tener en cuenta colmaos de múltiples palabras y hechos narrativos, aparentemente abastecidos por la materia de lo sensible, de la sensiblería; en extremo como argumentos falaces, para 
hablar de otros asuntos de carácter diacrónico: el stablishment ${ }^{9}$, su resistencia a ceder; la estrategia por sobrevivir a los cambios y las transformaciones sociales propuestas a partir de los siglos XVIII-XX.

Sin duda alguna, María Elvira utiliza más recursos para manipular el medio social y ponerlo a su favor, es decir, desarrolla una serie de enmascaramientos para engañar al otro patriarcal, pues ella desea gozar de los placeres sexuales de un hombre que en cierto sentido le es prohibido, inhibiendo a realizar cualquier acercamiento con él con actitudes distantes. Por eso obtener del cuento la información de que algo contractual se realiza, probablemente en la época en que ello se plantea, significa una verdadera revolución de lo que los idealistas llaman la "revolución del espíritu", y lo señalo, consciente de los vínculos que soporta el cuento, con categorías del Romanticismo con facetas de Idealismo.

Por otra parte, el cuento también invierte ciertas características intrínsecas ${ }^{10}$ al comportamiento social representado por lo masculino y por lo femenino, máxime en grupos culturales que forman parte del centro por la concentración simbólica y económica que arriba mencioné, contrario a las figuras femeninas que atraviesan el inter-texto patriarcal desde los griegos: a la mujer le corresponde semantizar en todas sus acciones, acciones propias de su género. Por eso, la capacidad de soportar en silencio los embates de los deseos no realizados, en particular los amorosos; mantener firmeza en la soledad y fidelidad por la ausencia del amado: tejer y destejer penas como se hace con una trama de hilos, les atribuyen a muchas de las mujeres en textos que son claves patriarcales de occidente, eso femenino que se resiste a ceder como algo interiorizado. 
En tal sentido, la actitud del ingeniero Carlos Durán, le proporciona atributos como los que menciono, se le construye a través de una variación de la feminización que opera en las claves del lenguaje literario y en las cláusulas del comportamiento social. Verlo en el cuento manifestando un berrinche de histeria femenina; sentirlo derrumbado y abatido ante la fría mirada de María Elvira, me parece un constructo social más propio de la mujer, que la que adorna la de un varón tradicional. Al fin de cuentas, en la tradición patriarcal, el hombre expresa su firmeza varonil en la fuerza que ejerce, en la dureza de un falo poderoso dispuesto para la penetración, Claro está, que en una sociedad "civilizada" como la que expresa el cuento, no vamos a obtener a un Carlos Durán que, como antiguo guerrero, tome por la fuerza a la hembra de su gusto y que pasa a ser de su propiedad después de haber vencido a los otros hombres como los oponentes.

Las reglas sociales que definen los alcances y los límites de lo que se ha entendido en nuestra literatura como la diada civilización/barbarie, inserta también las energías sexuales dentro de los límites de la transferencia. El modo de decir, de actuar y de hacer converger en la narrativa estudiada, son elementos que pretendidamente dirigidos a definir el triunfo de lo civilizado sobre lo bárbaro. También expresan el éxito de lo objetivo y racional, sobre los defectos de la subjetividad y la irracionalidad. Sin embargo, estas categorizaciones tan importantes, obedecen a la impronta histórica de sustitución cuando se han dado los hechos de la expansión europea en Latinoamérica.

Cierto esnobismo centralizador de los sectores culturales periféricos, circulan en la literatura, los proyectos educativos y en el interior ideológico definido por las clases político-económico poderosas, que surgen después de los mencionados procesos de emancipación de las colonias. El papel de 
los criollos es fundamental para entender así, la afectación de este modelo en la construcción de la identidad de América Latina, en la cual, debemos ubicar con toda precisión y definición comprensiva, a los sectores intelectuales, particularmente la de escritores como Quiroga y los que coinciden con él en tiempo y proyección, sobremanera la que se ejerce en los diseños educativos propuestos y llevados a cabo con la clara intención de los Estados Liberales, de generalizar lo que en la época se entiende como civilizador, laico, culto y por ende educativo.

Toda esta exposición, me lleva entonces a proponer la definición y la sistematización de los "modelos" que constituyen el análisis semiótico para evidenciarlos con las mismas palabras del cuento de Horacio Quiroga.

-Modelo masculino-y femenino patriarcal.
Aplicación de la semiótica social: El análisis multimodal

-Sentido común. -Re-significación de lo genérico. -Fronteras sociales y disyunciones de los actantes. -Prescripciones culturales del comportamiento: lo correcto/incorrecto.

En reiteradas ocasiones nos hemos referido a lo masculino como un constructo inscrito en el ámbito histórico-social, cuyo eje significante más explícitamente patente en la escritura del cuento, revela las condiciones reales en que los hombres se relacionan entre sí, esta vez, reuniendo varias de las cualidades que obtienen al estar inscritos sobre un telón de fondo que considero es la trama misma que permite la reunión de estos. 
Siguiendo como herramienta los lineamientos de la investigadora Marcela Lagarde (1996) utilizo dos términos que ella consigna con fines estrictamente de investigación, lo que se ha denominado como Teoría de Género.

La Teoría de Género planteada por la autora entiende que en cuanto al constructo sexual hay que hacer la distinción entre dos simultáneas características del desarrollo sexual en el ser humano. Género es todo lo que histórica y culturalmente se asigna a un individuo masculino o femenino. Sexo las características biológicas que determinan física o corporalmente, las diferencias obvias que están a la vista y son externas, físicas, de un hombre en relación a una mujer y viceversa.

En este doble sentido de la sexualidad humana, las características biológicas son consecuencia del desarrollo del feto como trama del material genético o lo que se conoce, como el $\mathrm{ADN}$; las otras, las de género, están directamente relacionadas con el grupo social al que se pertenece como especie social, dependiente de las relaciones parentales, por eso, resulta ser un conjunto de construcciones, algunas de carácter simbólico, otras culturales, que facultan al hombre o a la mujer, a manifestaciones del gusto y del comportamiento humano.

En cuanto al comportamiento de los varones que masculinizan la trama son tres y que los consignamos en orden lineal de aparición.

Carlos Durán, el ingeniero. A este le corresponde plantear el asunto "intrigante" que le sucede un día cualquiera en su vida. Su rutina presupuesta por el narrador se ve truncada en el mismo momento en que ha recibido el documento o la carta que llega a sus manos. La facultad humana 
en general le atribuye a cualquier miembro de la especie, a experimentar "eso" sorpresivo e "intrigante" pues la vida se altera, como consciencia que discurre en su propia linealidad sociológica y cultural.

Sin embargo, en este varón, el asunto mencionado, adquiere un matiz de mayor importancia y que ha de leerse como el inicio de lo que en la tradición literaria mucho después de los mitos y las leyendas, hace de portal para disponer a la aventura. Atributo mágico y simbólico tan vasto en la cultura literaria, por demás, hecho por el que se pasa a la otra dimensión hecho también que le da potencia iniciática a un individuo que ya sobresale por ser inteligente, viril y fuerte, convencido de la elección que lo coloca en la misión heroica. Lamentablemente en el caso de Carlos Durán, 1o leemos carente de cualquiera de esos referentes mitológicos citados, su aventura amorosa sorpresiva e inverosímil, si se puede llamar así, es otra cosa distinta y distante con el aventurero del cuento tradicional tan dotado de particularidades físicas y mentales que lo hacen sobresaliente, resistente y culmina su aventura triunfando.

Es claro en el cuento, que la mencionada "sombra" remita al lector a comprender que algo raro viene en su ayuda y elección gratuita como predestinación para el amor con la señorita del cuento. Probablemente su buena estrella o su buena suerte como le hace ver el doctor, corresponde más a un asunto más inmanente, pues arriba señalo que, en comparación con otros personajes aventureros y heroicos, el ingeniero Carlos carece de todo vínculo con una significación mítica correspondiente al héroe tradicional y legendario. 
Pienso que por el hecho de que es un varón contradictorio con la propia naturaleza social, según reza el patriarcalismo, es su resonancia y obsesión por la mujer de ojos hermosos y profundos, de palabras cálidas, de persistencia, haciendo valer más la dedicación esmerada a pesar de todos los altibajos de la relación con María Elvira, los rechazos encubiertos de la familia Funes, hay una fuerza poderosamente psicológica que lo mantiene en la lucha por un largo tiempo narrativo-teatral, hasta que él mismo aparenta desistir cuando monta toda la estrategia de su huida, de lo que es el poderoso impulso asignado para todo varón biológicamente capacitado: la elección de la mejor hembra y la perpetuación biológico-cultural de la especie.

Sin embargo, téngase en cuenta que el mundo social en que se colocan los personajes para desarrollar la trama seudo-amorosa, expresa las características propias de la modernidad sabedora de ser por antonomasia civilizada, culta y beneficiadora del orden público. Todo hombre civilizado moderno es el producto de años y la secuencia histórica en los que mucho de su salvajismo patriarcal ha domesticado la naturaleza masculina, su inconsciente atributo pulsional como inseminador en una doble dinámica patriarcal, esto es, en que produce y desperdicia un semen inútil en el sentido que apunta a la fertilidad y de la utilidad reproductora como el que se eyacula en casos como la masturbación o en la prostituta y el otro, destinado a potenciar lo más sagrado según el patrón mítico religioso Latinoamericano de cuño judeo-cristiano, es decir, el semen que fecunda el depósito uterino y que supone las expectativas más altas a las que se puede aspirar, concebir el primogénito, desde luego en el mejor de los casos varón, y sin defecto. Las tramas del teatro, el cuento, la novela y las leyendas de héroes, destinan miles de páginas a la consignación de este 
modelo, sobre todo, cuando el varón fundador de la familia, procede de un sector alto de la sociedad.

La mejor hembra, para decirlo de alguna manera, es aquella que, en el horizonte de los reproductores, representará sin duda alguna, todas las estructuras sociales que aseguren la perpetuación de la especie, la eficacia poderosa del semen como atributo masculino que concede los máximos beneficios a la hembra que se preña dentro de las normas de fertilidad honesta, es decir, la forma matrimonial consagrada a ello. Pero llegar a ese punto pienso clímax, no es algo que sucede porque sucede, para todo varón y en esto los casos son muy vastos en la literatura, hay un tiempo para la espera, para la prueba, para vencer escollos y triunfar. Por eso no creo que la despedida que hace Carlos Durán, sea un asunto desprovisto de todo rasgo estratégico. El planea presentarse vencido ante ella al extremo de confesar su locura y feminiza al declararse subordinado a la hembra, por la misma hembra que ambiciona. En pocas palabras, si no logró triunfar con su majadería y sus recriminaciones, triunfa por su pretendido vencimiento de ella con él, pero al fin de cuentas, lo exitoso de dicha empresa, trae sus frutos en el modelo semiótico que nos habla de patriarcalismo disfrazado o trans vestido de hembra, a la que le corresponden actos de extrema dedicación, de ternura y atenciones desbordadas para un miembro, y que, en el caso de María Elvira, me conecta con un artículo de lo femenino-niña.

Aún más, consecutivamente con Carlos Durán lo que me permite pensar su falsedad diacrónica, está en la estrategia que aplica antes de que él llegue al climax de esta. Todo en la relación es dado como un procedimiento sistemático para que Carlos alcance el beneficio de su disfrute a la perfecta unión y en consecuencia, a reproducirse con la mejor hembra estimada en 
el cuento por mucho, le llega por ese motivo fingido, extraño y raro para un lector lineal, y su esfuerzo heroico constará de la secuencia también fingidas de tener dudas o preguntas sin respuesta, aceptación moderada de un sino incomprensible desde el principio de la narración y que se agudiza in extremis, motivación a veces con cierto grado de desgano y hasta de enojo e incomprensión por la solicitud de la enferma que lo llama, paciencia y experiencias de angustia, desvelos confesos, pesadillas notorias cargadas de significación onírica de un inconsciente que lo recrimina y por último, desesperación y desajuste emocional. Su masculinidad yuxtapone sentimientos y racionalidad obsequiosa, en el diálogo tenso que sostiene con el doctor Ayestarain, y que como el mismo Durán señala:

Comenzaba ya a serme pesado el galeno, por eminente que fuese $-\mathrm{y}$ lo era- pisando un terreno con el que nada tenían que ver sus aspirinas (p. 106).

¿Y sabe usted -concluyó- a quien nombra cuando el sopor la aplasta?

-No sé... -le respondí, sintiendo que mi corazón cambiaba bruscamente de ritmo.

-A usted -me dijo, pidiéndome fuego.

Quedamos, bien comprende, un rato mudos.

-¿No entiende todavía? - dijo al fin.

-Ni una palabra... murmuré aturdido, tan aturdido como puede estarlo un adolescente que a la salida del teatro ve a la primera gran actriz que desde la penumbra del coche mantiene abierta hacia él la 
portezuela (...). Pero yo tenía ya casi treinta años y pregunté al médico qué explicación se podía dar a eso.

-Explicación? Ninguna. Ni la más mínima. ¿Qué quiere usted que se sepa de eso? Ah, bueno...Si quiere una a toda costa, supóngase que en una tierra hay un millón, dos millones de semillas distintas, como en cualquier parte. Viene un terremoto, remueve como un demonio todo eso, tritura el resto, y brota una semilla, una cualquiera, de arriba o de fondo, lo mismo da. Una planta magnífica (...) ¿Le basta eso? No podría decirle una palabra más. ¿Por qué usted, precisamente, que apenas la conoce, y a quien la enferma no conoce tampoco más, ha sido en su cerebro delirante la semilla privilegiada? [cursivas añadidas] ${ }^{11}$ ¿Qué quiere que se sepa de esto?

-Sin duda (...) -repuse a su mirada, siempre interrogante, sintiéndome al mismo tiempo bastante enfriado al verme convertido en sujeto gratuito de divagación cerebral, primero, y en agente terapéutico, después (pp.107-108).

El doctor Ayestarain otro de los masculinos de la trama cuyos intereses por la señorita burguesa se expresan por medio de algo de indiscreción y de competencia con quien él considera ser el hombre más afortunado que conoce y que en cierto sentido, echa un pulso con el ingeniero, pues este es si se quiere, un rival en un sentido inestable que se puede verificar en otras rivalidades más propiamente elaboradas en la literatura, sobre manera, la que lleva las intrigas del caso y a extremos como duelos y distintos ejemplos de exterminación del otro. El ingenio competitivo entre masculinos enfrentados no obtiene consecuentemente, aspectos de lealtad, de parentesco, de amistad filial si de competir por la mujer que se desea se trate. En este juego, la mujer se construye como el trofeo por el que los 
hombres luchan en los espacios que, en términos generales, podríamos entender como "la arena" con todas sus variantes polisemánticas.

Los alcances para comprender el por qué las cosas suceden contradictoriamente, colocan al doctor en una especie de encrucijada pues, por un lado, no entiende como vimos en la cita textual del cuento arriba transcrita, por qué el semen que puedan aportar millones de hombres, no sea el que lógicamente se destine a la mejor semilla que sobrevive a la catástrofe fatal, el brote de la semilla y la semilla que se le destina. Por otro lado, los sentimientos encontrados, también aturden las explicaciones lógicas que obviamente debería tener un médico para analizar el estado de salud de la enferma, por eso, el panorama de conocimiento a que alude, se torna algo confuso en el nivel racionalmente lógico cuando se yuxtaponen las observaciones del hecho que hace respectivamente Durán y que se mezclan con las del doctor Ayestarain:

Vengo de lo de Funes. Es la cosa más extraordinaria que haya visto en mi vida. Metempsicosis, espiritismos, telepatías y demás absurdos del mundo interior, no son nada en comparación de este, mi propio absurdo, en que me veo envuelto. Es un pequeño asunto para volverse loco. Véase:

(Carlos) Fui a lo de Funes... Mi condiscípulo (Ayestarain) me contó entonces lo que en resumen es esto:

Cuatro o cinco noches antes, al concluir el recibo en su propia casa, María Elvira se había sentido mal -cuestión de un baño demasiado frío esa tarde, según opinión de la madre. Lo cierto es que había pasado la noche fatigada, y con un buen dolor de cabeza. A la mañana siguiente, mayor quebranto, fiebre; y a la noche, una 
meningitis con todo su cortejo. El delirio, sobre todo, franco y prolongado a más no pedir. Concomitantemente, una ansiedad angustiosa, imposible de calmar. Las proyecciones psicológicas del delirio, por decirlo así, se erigieron y giraron desde la primera noche alrededor de un solo asunto, uno solo, pero que absorbe la vida entera. En una obsesión -prosiguió Ayestarain- una sencilla obsesión a $41^{\circ}$. La enferma tiene constantemente fijos los ojos en la puerta, pero no llama a nadie. Su estado nervioso se resiste de esa muda ansiedad que la está matando, y desde ayer hemos pensado con mis colegas en calmar eso... (p. 107).

En un sentido de modulación de la competencia entre masculinos, la claridad de las intenciones que obtiene uno en relación al otro, explicitan una variedad de justa por el espacio de dominación de la hembra, el derecho a la inseminación, asunto que ya señalé arriba, pero que es necesario volver sobre el mismo, para que se perciba con mayor facilidad que entre varones, el constructo revela siempre sentimientos de aversión y de franca competencia. En este asunto en particular, se ha de estimar que a diferencia de Ayestarain, Durán carece de la mínima relación con el círculo Funes y también con el doctor, a quien reconoce como uno más de los alumnos que cursaron en el Colegio Nacional, probablemente el bachillerato. Sin embargo, la relación del doctor tiene rasgos más definidos con los Funes, he ahí el "interés profesional” que suele manifestar por el caso de la enferma, su interés sexual y su ambición o deseo de ascenso social también por ella. 
El doctor juega un rol semiótico interesante porque es diverso distribuyendo las cargas del sentido de lo que se conforma a las intenciones del contrato-alianza con Luis María el patriarca de la familia Funes, por un lado, pretendidamente en el cuento, uno de estos roles e el ético profesional de la salud, respectivo con el juramento Hipocrático que es el ético profesional, y el otro el "amoroso", del cual expreso ciertas dudas que sea este realmente. Más bien detrás de su supuesto interés amoroso, el doctor busca el mismo estatus social que le brindaría el considerarse un miembro de la reputada familia.

El exceso de servilismos que el doctor asume en la trama del cuento, defendiendo los intereses de la familia y en particular, la de Luis María, tiene más ligamen de sentido con el que significa el valor de mayor o menor importancia que se obtiene como miembro de uno u otro sector social. Aún más, si se argumentara para contradecir mi teoría de lectura en el hecho de que ser médico en la sociedad implica un valor de superioridad social, es admisible, pero parcialmente, pues en el contexto histórico y en la sociedad en que se coloca un actante de la medicina, la práctica disciplinaria se ha consolidado y multiplicado dadas las políticas contextuales de la salud pública desarrolladas por los países de la modernidad pre capitalista; se logra que la educación sea parte esencial para proveer a las necesidades de un país desarrollista, en este caso, el de la salud pública como beneficio altamente estimado por sus efectos en la producción económica. La definición de ser un ingeniero como en el caso de Carlos Durán, independientemente que no se especifique cuál es, también remite al criterio de desarrollo social en la consolidación de los estados nacionales que constituyen como proyectos desarrollistas todos los países que conforman América Latina en las primeras décadas del siglo XX. 
-Veamos Durán: usted comprende de sobra que no he venido a verlo a esta hora para hablarle de pavadas; ¿no es cierto?

-Me parece que sí -no pude menos que responderle.

-Es claro. Así, pues, me va a permitir una pregunta disparatada:

-¿Qué clase de inclinación siente usted hacia María Elvira Funes?

¡Ah, ah! ¡Por aquí andaba la cosa, entonces! ¡María Elvira Funes, hermana de Luis María Funes, todos en María! ¡Pero si apenas conozco a esa persona! Nada extraño, pues, que mirara al médico como quien mira a un loco.

-¿María Elvira Funes? -repetí-. Ningún grado ni ninguna inclinación. La conozco apenas. Y ahora...

-No, permítame -me interrumpió-. Le aseguro que es una cosa bastante seria... ¿Me podría dar palabra de compañero de que no hay nada entre ustedes dos?

-¡Pero está loco! -le dije al fin-. ¡Nada, absolutamente nada! Apenas la conozco, vuelvo a repetirlo, y no creo que ella se acuerde de haberme visto jamás. He hablado un minuto con ella, ponga dos, veces, en su propia casa y nada más. No tengo, por tanto, le repito por décima vez, inclinación particular por ella.

-Es raro, profundamente raro... -murmuró el hombre, mirándome fijamente (p. 106).

El duelo adquiere un valor interesante de confrontaciones, como instancias por las que claramente fluyen las legítimas justas entre machos que se 
disputan el amor de la mujer deseada y estriban en una rica amalgama semiótica con el valor de uso y de cambio que ha significado la mujer en la historia social de occidente. El cinismo entre hombres que conocen al adversario, obtiene igualmente valores de entre dicciones agudas que llenan el espacio tranquilo, ordenado y burgués interno. No hay violencia en el sentido de desorden ni mucho menos de derramamiento de sangre, golpes o venganzas, pero si la tensión que colma las circunstancias de lenguajes presémicos, es decir, sospechas que preludian la confrontación hipócrita teatral de los personajes masculinos. Leamos:

Ayestarain acaba de salir. Me ha dicho que la enferma sigue mejor, y que mucho se equivoca o me veré uno de estos días libre de la presencia de María Elvira.

-Sí, compañero -me dice-. Libre de las veladas ridículas, de amores cerebrales y ceños fruncidos... ¿Se acuerda?

Mi cara no debe expresar suprema alegría, porque el taimado galeno se echa a reír y agrega:

-Le vamos a dar en cambio una compensación...Los Funes han vivido estos quince días con la cabeza en el aire, y no extrañe, pues, si han olvidado muchas cosas, sobre todo en lo que a usted se refiere...Por lo pronto, hoy cenamos allá. Sin su bienaventurada persona, dicho sea de paso, y el amor de marras, no sé en qué hubiera acabado aquello... ¿Qué dice usted?

-Digo- le he respondido- que casi estoy tentado de declinar el honor que me hacen los Funes, admitiéndome a su mesa.

Ayestarain se echó a reír. 
-¡No me embrome!... Le repito que no sabía dónde tenían la cabeza...

-Pero para opio y morfina, y calmante de mademoiselle, sí ¿eh? ¡Para eso no se olvidaban de mí!

Mi hombre se puso serio y me miró detenidamente.

-¿Sabe lo que pienso, compañero?

-Diga.

-Que usted es el individuo más feliz de la tierra.

-¿Yo, feliz?...

-O más suertudo. ¿Entiende ahora?

Y quedó mirándome. ¡Hum! -me dije a mí mismo-: O yo soy un idiota, que es lo más posible, o este galeno merece que lo abrace hasta romperle el termómetro dentro del bolsillo. El maligno tipo sabe más de lo que parece, y acaso, acaso...Pero vuelvo a lo idiota, que es lo más seguro.

-¿Feliz?...repetí, sin embargo-. ¿Por el amor estrafalario que usted ha inventado con su meningitis? (p. 113).

Y de cumplir contratos sociales se trata. Las relaciones sociales no son posibles sin que cada uno de los individuos como entes sexuales, estén inscritos en su propio y característico ámbito de pertenencia. Las variaciones de ello acarrean lo que ya suponemos, el castigo, la exclusión y en caso extremo el confinamiento o la muerte. 
Por eso los términos masculinos en que se ha firmado una serie de cláusulas contractuales, pasan por el personaje coadyuvado al patriarcalismo y personalmente interesado en que su espacio, se le reconozca y se le respete. Las pretendidas aclaraciones, remiten a los asuntos que están en juego y que por supuesto pienso, redoblan lo mismo que el hermano de María Elvira cree debe considerarse como un pacto entre gente civilizada, pero distinguida por alcurnia del resto de los miembros de la sociedad.

(Carlos) "En el camino -hemos ido al águila, a tomar el vermouthme ha explicado bien claro tres cosas. (Ayestarain)

$1^{\circ}$ Que mi presencia al lado de la enferma era absolutamente necesaria, dado el estado de profunda excitación-depresión, todo en uno de su delirio-. $2^{\circ}$ Que los Funes lo habían comprendido así, ni más ni menos, a despecho de lo raro, subrepticio e inconveniente que pudiera parecer la aventura, constándoles, está claro, o artificial de todo aquel amor. $3^{\circ}$ Que los Funes han confiado sencillamente en mí educación, para que me dé cuenta-sumamente clara- del sentido terapéutico que ha tenido mi presencia ante la enferma, y la de la enferma ante mí.

-Sobre todo lo último ¿eh? -he agregado a guisa de comentario-. El objeto de toda esta charla es éste: que no vaya yo jamás a creer que María Elvira siente menor inclinación real hacia mí. ¿Es eso?

-¡Claro! -se ha encogido de hombros el médico- Póngase usted en el lugar de ellos... [cursivas añadidas]. ${ }^{12}$ (p.114). 
Luis María Funes a quién ya hemos leído como el patricio por excelencia en varios momentos de este estudio, por eso para no repetir más lo mismo ya señalado, creo que el uso del pronombre personal "ellos", conjuga como la mima gramática formal estipula, la existencia de otras terceras personas en forma plural, en este caso, ellos en su forma de género masculinizador.

Es interesante que dentro de la noción gramatical, las mujeres, María Elvira, la madre y la otra hermana, queden subsumidas con eso otro plural masculino. Las estrategias patriarcales del lenguaje in-visibiliza con todo propósito circunscribir lo femenino dentro del círculo central dominado por el hombre, dirá Pablo de Tarso, “cabeza de la mujer”, es decir, el que piensa la que no puede hacer dicha actividad, pues no ha sido dotada, según los patricios griegos, para tales fines razonables e iluminados. Ellos, los hombres, son seres de naturaleza superior en cuanto a todo lo que implique conocimiento racional.

Es interesante que las mujeres del cuento sean dadas a través de la resignificación solo como mujeres: la madre viuda, las señoritas María Elvira y Angélica, un conjunto de personajes que repiten hasta la saciedad, los rituales que le son propios a mujeres encantadoras, que se mueven solo dentro del ámbito cerrado de la casa y que de vez en cuando, asisten a alguna actividad social de rango superior. Pero ellas, las mujeres, carecen de todo referente que nos haga a los lectores y lectoras, estimarlas como profesionales o como mujeres proveedoras. El capital económico a favor de ellas, administrado por Luis María, se expresa como un favor también de poder que les niega la singularidad de nuestro tiempo y no de principios del siglo XX en una sociedad periférica de los centros de poder cultural, las relaciones simétrico-profesionales entre géneros. 
Pero todo "ello" propio de "ellos" como vengo señalando, también es diacrónico con la gramática formal de la tercera persona del plural en las conjugaciones verbales, en otro sentido, en el sentido más a la vista según se ve en la cita textual del cuento arriba consignada, es también lo que lo que indica a los Funes como gente rica, poderosa e importante dentro de la sociedad implicada. Tiene mucha razón y por ende, actualidad de competencia, Mijail Bajtín cuando teoriza a partir de la centralización de la palabra como clave para leer cómo en las distintas sociedades, se han confrontado fuerzas centrípetas y centrífugas para ordenar el mundo social. Por eso el lenguaje, la gramática dada a través de este y a pesar también, contiene las fuerzas que crean el signo de poder, el enunciado alternativo del poder propio y del ajeno como lo está en la acepción “ellos”, aunque suene desprolijo, los varones Funes, los ricos y poderosos económicamente. Miembros y sujetos de un clan fundado por el padre muerto y perpetuado por Luis María.

Es interesante, y en esto no voy a insistir más porque en cierto sentido ya lo dije, la racionalidad del patricio es más lúcida, en tanto y en cuanto soporta y resuelve todas las situaciones adversas que sufre la familia nuclear, en todo caso, se trata de un rostro enmascarado y solo circunstancial, pues su dependencia obsesiva estimulando el órgano bucogenital consumiendo cigarrillos, lo revela como una persona nerviosa, y en consecuencia, disonante en cuanto al poder que ejerce de forma enmascarada, más del lado de lo frágil y por tanto, evasivo y estratégico cuando se trata de ocultar su sensibilidad. Así el verdadero juego de poder que se le transfiere por herencia, lo realiza encauzándolo a través de dos extensiones significativas, como lo es la misiva rubricada por su nombre y por supuesto, la que realiza a través de su aliado defensor de sus propios intereses, el médico de cabecera Ayestarain. 
(Carlos) Fui a lo de Funes. Luis María me llevó al escritorio. Hablamos un rato, esforzándonos como dos zonzos -puesto que comprendiéndolo así evitábamos mirarnos-, en charlar de bueyes perdidos. Por fin entró Ayestarain y Luis María salió, dejándome sobre la mesa el paquete de cigarrillos, pues se me habían concluido lo míos. Mi ex condiscípulo me contó entonces lo que en resumen es esto (...) (p. 107).

En otro singular y relacionado sentido, Luis Funes como cabeza de la familia, como varón asentado sobre las tradiciones patriarcales, no expresa más que pocas apariciones directas que como actante muy principal a mi entender, debería tener. Pero eso no viene en detrimento de su rol, constituido por toda una gama de meta presencias, precisamente las que obtiene por constituirse en el directamente implicado con el patriarcalismo vigente. Más bien, él es el muchacho discreto, de pocas palabras, que se le conoce o se le evidencia, a través de algunas de las observaciones que lo revelan en su parte frágil. Hemos visto ya las que expresa el doctor hacia el ingeniero, veamos otra para concentrar la lectura en un hecho narrativo que desenmascara las auténticas intenciones o los cálculos mediatizados en lo que el texto dice, piensa este personaje políticamente más cauto:

-Y usted- me dijo la madre sonriendo-, ¿ha descansado del todo de las fatigas que le hemos dado?

-¡Oh, eran muy poca cosa!...Y aun -concluí riendo también- estaría dispuesto a soportarlas de nuevo...

María Elvira se sonrió a su vez.

-Usted sí; pero yo no, ¡le aseguro! 
La madre la miró con tristeza:

-¡Pobre mi hija! Cuando pienso en los disparates que se te han ocurrido...En fin -se volvió a mí con agrado-. Usted es ahora, podríamos decir, de la casa, y le aseguro que Luis María lo estima muchísimo.

El aludido me puso la mano en el hombro y me ofreció cigarrillos.

-Fume, fume, y no haga caso.

-¡Pero, Luis María -le reprochó la madre, semiseria-, cualquiera creería al oírle que le estamos diciendo mentiras a Durán!

-No, mamá; lo que dices está perfectamente bien dicho; pero Durán me entiende.

Por supuesto que el ingeniero entiende...que en aquella mesa a la que ha sido invitado cordialmente a comer, no es más que un ritual todo intencionado a repetir lo que ya se ha dicho, pero ahora en el lenguaje directo de quien se sabe el poseedor del enclave de poder, dueño y señor de la estrategia que consolida al clan supeditado a los criterios del patriarca. Concluye entonces Carlos Durán:

Lo que yo entendía era que Luis María quería cortar con amabilidades más o menos sosas; pero no se lo agradecí en lo más mínimo (p. 117).

María Elvira Funes, la típica mujer caótica y como su madre la llama, la que dice disparates, la que con "su enfermedad" demuestra los pocos avances o derechos reconocidos pues la enfermedad no está en su cuerpo, sino en la sociedad enferma que la restringe a satisfacer sus deseos, y en su 
caso, enferma de amores como se concibe en la Edad Media que ciertos trastornos físicos, corresponden a un mal de época por estar enamorada, por eso, la disyuntiva me conduce a pensar en las restricciones que cuenta una mujer, para hacer la elección del hombre de su gusto. La búsqueda erótica, la insatisfacción, choca como deseo sexual femenino, contra el muro de poder de la sociedad inhibidora que, en el ámbito patriarcal, ejerce el macho primordial sobre las hembras del clan. Pese a los pretendidos avances de la sociedad moderna, como la que asume el cuento de Quiroga, la mujer está aún sujeta como si nada hubiese modificado el paisaje social en materia de libertades sexuales, como también es muy probable que obedezca más a los estereotipos de uso muy frecuente en la Literatura Latinoamericana, útiles para caracterizar a las clases tradicionalmente conservadoras que mantienen su férrea moral pública.

Otro sentido al que no me he referido en cuanto a los rasgos de la señorita Funes y que considero debe señalarse y descifrarse obligatoriamente por su fuerte valor semiótico del modelo, es la apropiación de toda la persona que es vista en su conjunto descriptivo, por el rasgo más sobresaliente que señala encantado Carlos Durán: los ojos de ella, por extensión la mirada seductora o demandante, así los detalles simples como ver, refuerzan las tensiones eróticas, transfiriendo el deseo al primer plano visual de los actantes poseídos por esa pequeña satisfacción por ver lo ajeno en los distintos escenarios, especialmente los que corresponden al ámbito familiar o privativo.

Por la frecuencia en este cuento del ejercicio de mirar, obtenemos los vínculos entre personajes que aprehenden lo ajeno y dan al lector, pero también para la trama misma tal y como está construido el sentido, 
notaremos en el contexto social lo que no expresan si no lo hace el narrador, pues algo de eso es prohibido y requiere de las cautelas propias, para mantener buenas relaciones entre gente educada, o gente que celebra un cierto ritual de culto social manifiesto, cuando se tiene franca claridad de la ubicación espacio-social. Las relaciones amorosas, se convierten en estrategias digamos "comedidas" para ser consecuentes con las construcciones narrativas del uso frecuente con que se trata en la literatura dirigida a los sectores burgueses, y que desde el siglo XIX, explora más en el campo estricto y restringido de los sentidos y lo sensorial, en suma lo que tenga que ver con la confrontación personal de sensaciones, a veces contrarias a los sistemas educativos, ora en conflicto, ora imposibles de precisar, pero siempre remiten a las pasiones encontradas con acuerdos o con desacuerdos entre conciencias particulares y tensiones con el objeto del deseo. Ello derrama literariamente, francas oleadas de sentidos que se desbordan, porque el deseo define a los actantes como humanos que son, como personajes ciertamente conflictivos al no poder adecuar el deseo facultativo sexual de la posesión coital, a las cláusulas sociales que muy por el contrario restringen o anulan por aquello del respeto ajeno, la expresión de la decencia, la educación moral y lo religioso como discurso restrictivo que culpabiliza, entre otras situaciones limitantes, tal y como es la narración de hechos de la erótica entre Carlos Durán y María Elvira, la señorita Funes.

En el cuento, la relación entre ambos personajes observa, a propósito de ver, dos momentos clave. El primero que corresponde al período en que ella se enferma, y en la que el observador intenso es Carlos Durán que se ve, digamos, atrapado por la mirada y las palabras delirantes de María Elvira que le profesan su amor. El segundo, al que abastezco con algunas de las citas pertinentes, porque quiero darle más énfasis y porque para esta 
investigación, consiste detenerse más en el repaso obsesivo erótico de Durán hacia la mujer vista como una disyunción simultánea entre las expectativas que ella misma ha sembrado en el corazón del ingeniero y lo que en realidad ella no cumple cuando supera la enfermedad (¿enfermedad?). Algo graciosamente impune, como si se tratara de una mujer que ha comprometido su palabra y no la cumple, la convierte por extensión en una mentirosa y manipuladora, pero también en otra mujer por este hecho, deliciosamente seductora. En la moneda como artículo de intercambio con valor de uso y de cambio, con el troquel, se acuñan las dos caras virtuales de eso informe que se da como revelación amorosa. Amor y odio, las delicias de los sentimientos que tensan eróticamente a los sujetos ardientes, corroboran las inhibiciones propias de una sociedad compleja en consonancia con sus tabúes.

Entre tanto, cuantas veces podía, sin llamar la atención, fijaba los ojos en María Elvira. ¡Al fin! Ya la tenía ante mí sana, bien sana [cursivas añadidas]. Había amado una sombra, o más bien dicho, dos ojos y treinta centímetros de brazo, pues el resto era una larga mancha blanca. Y de aquella penumbra, como de un capullo taciturno, indiferente y alegre, que no me conocía. Me miraba como se mira a un amigo de la casa, en el que es preciso detener un segundo de ojos cuando se cuenta algo o se comenta una frase risueña. Pero nada más. Ni el más leve rastro de lo pasado, ni siquiera la afectación de no mirarme, con lo que yo había contado como último triunfo de mi juego. Era un sujeto -no digamos sujeto, sino ser- absolutamente desconocido para ella. Y piénsese ahora en la gracia que me hacía recordar, mientras miraba, que una noche esos mismos ojos ahora frívolos me habían dicho a ocho dedos de los míos: 
-Y cuando esté sana... ¿me querrás todavía?

¡A qué buscar luces, fuegos fatuos de una felicidad muerta, sellada a fuego en el cofrecillo hormigueante de una fiebre cerebral! Olvidarla...Siendo lo que hubiera deseado, era precisamente lo que no podía hacer.

Más tarde, en el hall, hallé modo de aislarme con Luis María, más colocando a éste entre María Elvira y yo; podía así mirarla impunemente, so pretexto de que mi vista iba naturalmente más allá de mi interlocutor. Y es extraordinario cómo su cuerpo, desde el más alto cabello de su cabeza al tacón de sus zapatos era un vivo deseo, y cómo al cruzar el hall para ir adentro, cada golpe de su falda contra el charol iba arrastrando mi alma como un papel (p. 117).

Es interesante la intensa carga erótica en que queda subsumida la mujer como sujeto del deseo, pero también es interesante el doble juego visual que otorga valoraciones que a la postre, califican y des-califican el papel protagónico de la mujer dentro de las posibilidades que la ajustan al patriarcalismo, pues algo deliciosamente delictivo en ella, salido de las circunstancias, hace que el macho la explore con sus ojos pletóricos de deseos inconfesables, cosa que sabemos solo dentro del fuero interno que también está previsto por el narrador en cuanto a los personajes restringidos por el contexto.

En todo caso, las premisas de ese algo deliciosamente culpable e impreciso, aunque suene contradictorio en la trama, algo demoniaco, peligroso respectivamente de parte de la mujer, quizá demonio, quizá seductora innata, estriba en haber desatado en el observador macho, la visión de su 
conjunto contradicciones materialmente eróticas y ambivalentes. Se incide por lo demás, en el hecho de que la hembra sea por defecto la "culpable" de las reacciones involuntarias de un macho excitado o provocado sexualmente y que puede en otros casos como a los que apelan los procesos que realizan las instancias judiciales por violación y otras prácticas sumarias; el argumento que favorece a la parte demandada, confiesa padecer de deseos más allá de sus propias fuerzas suscitados por la víctima.

Por eso, es interesante que María Elvira atraiga este asunto y le agregue algo más a algo tan fuerte como la instancia seductora, ella demuestra esa actitud burlona, cínica y mesuradamente sádica de la mujer que sabe que es vista y deseada. Así se exacerba la tensión que ya sufre el macho seducido y restringido a un juego de provocaciones, piensa el patriarcalismo, delictivos y necesarios biológicamente para la perpetuación de la especie.

Volvió, se sonrió, cruzó rozando a mi lado, sonriéndome forzosamente, pues estaba a su paso, mientras yo, como un idiota, continuaba soñando con una súbita detención a mi lado, y no una, sino dos manos, puestas sobre mis sienes.

Y bien, ahora que me has visto de pie, ¿me quieres todavía?

¡Bah! Muerto, bien muerto, me despedí y oprimí un instante aquella mano fría, amable y rápida (pp. 117-118). 
-El modelo literario cinematográfico: espacio privado y público.

-La vanguardia como estilización diversa. -La liberación narrativovisual del sujeto del deseo como algo ordinario-extraordinario.

Con bastante frecuencia lo que aporta al modelo narrativo utilizado el cine como tecnología de la imagen, del tiempo y del espacio, también se fue adaptado algunos de estos recursos a la novela y el cuento Latinoamericano de vanguardia. Mi tesis consiste en afirmar que los recursos visuales en particular que le brinda el cine a la estética literaria moderna, o la manera moderna de describir el contorno, el espacio social y natural, la ciudad y las relaciones humanas de los personajes, se adquieren de las prácticas cinematográficas tan en boga en el siglo a finales del siglo XIX y por ende el siglo XX. Por supuesto que no haré un amplio despliegue de esta afirmación porque lo que apenas apunto, requerirá de más espacio para desarrollarse que el que brinda un artículo para una revista académica y que, de hecho, es materia de otro enfoque y una más extensa investigación.

Si quiero que se considere que el desarrollo tecnológico del lente de la cámara fotográfica primero, y el de la cámara cinematográfica poco después del anterior, inciden en la manera de ver el mundo con otros ojos nuevos, se trata de la acción dinámica y sorprendida de un nuevo visualizador que observa la imagen que sostiene la fotografía, y el que observa dentro de otra caja oscura como es la sala destinada al cine. Se exploran por tanto consecutivamente, las imágenes de lo que se considera íntimo, otras veces lo prohibido, lo oscuro que producen los bajos instintos venéreos, en que antes de la revolución de la imagen sexual, que en principio es un artículo que se consume en un espacio privado, se convierte luego, ya rotas las cadenas de la censura, en el erotismo fotográfico y por supuesto, en el cine erótico y el pornográfico. 
Ya la pintura expone eso vedado a la vista, como se podrá observar en el cuadro que pinta Goya de La Maja Desnuda y que se coloca en la pared de atrás donde se expone públicamente a La Maja vestida. El díptico nos remite a la escisión entre lo permitido y lo prohibido también, aunque hoy veamos tanta carga erótica en una como en otra y cuestiono si más bien la que se debió ocultar era la vestida, pues el erotismo visual, puede traspasar las telas, no así la carne. También sucede algo semejante en el caso de lo fotográfico, y en la tecnología de la imagen implicada en la elaboración de la cinematografía: ambas prácticas novedosas en el período que atañe a las vanguardias literarias, soportan las instancias reveladoras de lo privado con escenas doblemente provocativas, pues son objetos de observación de carácter privado y de carácter público.

Las vanguardias, como también se ha dicho, rompen los viejos moldes con lo que se describe el tabú de lo sexual, derriba la manera correcta de observar, de mirar al otro o a la otra, de contener el poder que crea la distancia entre lo propio y lo ajeno, la suficiente para no sufrir los embates de ese delito y infracción protocolaria en sumo grado punible e indecente. La mirada adquiere entonces en las vanguardias, nuevos bríos a partir de la oferta que hace el cine con otros modelos de ver y de aprehender el contorno, pero principalmente por lo que tratamos, de la exposición del cuerpo social y del cuerpo humano al que pertenece, como es el retrógrado de las mujeres que hoy "ven" el exterior con la imposición de la burka musulmana que pretende volver a la antigua moral que dicta el Corán, evidentemente para los occidentales, se les reduce el campo de visión de ellas y también, se les uniforma para ser vistas en la circulación por las ciudades atiborradas, y que se consideran lugares culposos pletóricos de tentaciones que provocan al mal a las frágiles mujeres. Al fin de cuentas, 
el control del ser humano, en especial el de la mujer, continúa siendo algo más frecuente en la actualidad que lo que este investigador plantea.

También las vanguardias artísticas, asumen como algo propio las formas en que el lente captura con todos sus artificios la captura de la realidad y la descompone analizándola por igual en su conjunto y en sus partes de sentido visual semiótico. Prácticas literarias como son La última niebla (1934) y La Amortajada (1938) de María Luisa Bombal y el Cagiostro (1934) de Vicente Huidobro, me remiten más al uso de efectismos artificiosos que apelan a la realidad como algo escondido entre las nieblas y las penumbras, en la memoria de la mujer que observa su vida pasada desde el lecho de muerte por unos ojos entre abiertos, como lo hace un diafragma, o por la mirada del violento mago que obtiene esa mirada penetrante que subyuga todo a su paso. ${ }^{13}$

Se podría considerar que hay un desarrollo histórico interesante y sumamente complejo en cuanto a las "maneras de ver", y de mirar, de pormenorizar eso que entendemos en todos los idiomas como la realidad, sea esta la tangible por experiencia propia y directa con los objetos, o la referida, es decir la que nos hacen ver otros u otras relatoras como son las narraciones que pueden hacerse con las cansadas palabras de siempre, las literarias o las que se apoyan en tecnologías para la comunicación audiovisual. La verdad sea dicha, pero entre ver y tocar, como piensan los griegos, no hay distinciones, pues el verbo ver, es acariciar lo visto, de ahí que el erotismo sea tan posesivo e indiscreto, tan fuerte como el expresado arriba por el ingeniero Carlos Durán (pp. 117-118). 
La literatura que hace usos distributivos de los elementos estilísticos como los que apunto en el título de esta investigación, a saber, lo in(debido), hace también el cálculo si se puede decir así, de los límites y los alcances en que un punto de vista prohibido, apunta también a la estrategia de uso mesurado o desbordado; dependerá de la pasión y de las posibilidades que da el entorno social. Pero y sin duda alguna, la cinematografía revolucionó la estrategia que ya había usado la literatura que se vale de asuntos enrarecidos, es decir, fantásticos, mágicos, extraños, inverosímiles, y en suma, poco familiares o usuales. No es la misma sensación recorrer en la noche la misma calle, la misma de siempre para que el personaje x o y llegue a su ansiado hogar después de salir del trabajo y compartir unas cuantas copas con los amigos. No es lo mismo, si en una cualquiera, baja la densidad de la luz del alumbrado público, porque ha caído una densa neblina que se mete por doquier. Esa noche el viajero de siempre, se percibe algo más húmedo en el ambiente, pero también eso otro siniestro que lo ha envuelto en una especie de mortaja de silencio, de terror mortal.

Pero también la intriga primero legendaria y literaria después, generan expectación desde tiempos atrás, mucho antes que el cine, algo truculento que nos pone siempre en vilo Las pesquisas que podamos aplicar para resolver los enigmas, se toman de la narración clásica y nos llevan como el hilo de Ariadna, a entrar en el laberinto y a salir victoriosos por las mismas encrucijadas donde todo es tan sorpresivo como encontrase cara a cara con el Minotauro. Así y por igual, considero que las tramas humanas, urden en el tejido social, como lenguajes codificados propios y característicos de específicos sectores encerrados dentro del signo y el significante, o del símbolo materializado por las clases sociales. Sin esto no podríamos entender cabalmente mucho de lo que describe Marcel 
Proust en sus casi inagotables novelas, ni tampoco mucha de la literatura extraordinaria como la de León Tolstoi, el genio Dostoyevsky, el insidioso Gogol, pero tampoco los horrores del entorno que nos hace penetrar Kafka o Donoso; todos los autores y todas las autoras de la novela y el cuento negro.

Me refiero entonces al asunto de la recurrencia de la mirada como metáfora de la percepción de todo lo que no está claro y que se acompaña de muchas dudas y cuestionamientos sumarios, pues por igual del viejo cuño de ello en la literatura antigua, la de las vanguardias insta a resolver dilemas creados por los deseos que solo la mirada percibe, observa, discurre como sustitución de deducir y analizar. Es este el caso que se percibe en cuanto a María Elvira en una primera instancia narrativa y la de Carlos Durán, en otra posterior. Debemos por consecuencia con el narrador, observar la radiante escena del baile en la casa de otros burgueses, la familia Rodríguez Peña, pero sobremanera, hacer de testigos visuales de la tensión de la pareja que no puede más que concebirse, dentro del ámbito mismo donde confluyen dos ideologemas o visiones de mundo en franca lucha por vencer al otro o a la otra. Obviamente, el disfraz del reclamo o de la demanda amorosa como recurso que engaña los ojos del lector, nos hace que veamos con torpeza lo que en realidad sucede entre ambos: la divergenciaconvergencia con el que se mira los ajenos desde lo propio.

Dígame María Elvira -me incliné-. ¿Usted no recuerda nada, no es cierto, nada de aquella ridícula historia?

Me miró muy seria, con altivez si se quiere, pero al mismo tiempo con atención, como cuando nos disponemos a oír que a pesar de todo no nos disgustan. 
¿¿Qué historia? -dijo.

-La otra, cuando yo vivía a su lado... lo hice notar con suficiente claridad.

-Nada... absolutamente nada.

-Veamos; míreme un instante...

¡¡No, ni aunque lo mire!... -me lanzó una carcajada.

¡¡No, no es eso!... Usted me ha mirado demasiado antes para que yo sepa...Quería decirle esto: ¿No se acuerda usted de haberme dicho algo...dos o tres palabras, nada más...la última noche que tuvo fiebre? María Elvira contrajo las cejas un largo instante, y las levantó luego, más altas que lo natural. Me miró atentamente, sacudiendo la cabeza:

-No, no recuerdo...

-¡Ah! -me callé.

Pasó un rato. Vi de reojo que me miraba aún.

-¿Qué?... -murmuró.

-¿Qué... qué? -repetí

-¿Qué le dije?

-Tampoco me acuerdo ya...

-Sí, se acuerda... ¿Qué le dije? 
-No sé, se lo aseguro...

-Sí, sabe... ¿Qué le dije?

-¡Veamos! - me aproximé de nuevo a ella-. Si usted no recuerda absolutamente nada, puesto que todo era una alucinación de fiebre, ¿qué puede importarle lo que me haya o no dicho en su delirio?

El golpe era serio. Pero María Elvira no pensó en contestarlo, contentándose con mirarme un instante más y apartar la vista con una corta sacudida de hombros.

-Vamos- me dijo bruscamente-. Quiero bailar este vals.

-Es justo -me levanté-. El sueño del vals que bailábamos no tiene nada de divertido.

No me respondió. Mientras avanzábamos al salón, parecía buscar con los ojos a algunos habituales compañeros de vals.

-¿Qué sueño de vals desagradable para usted? -me dijo de pronto, sin dejar de recorrer el salón con la vista.

-Un vals de delirio...no tiene nada que ver con esto -me encogí a mi vez de hombros.

Creí que no hablaríamos más esa noche. Pero aunque María Elvira no respondió una palabra, tampoco pareció hallar al compañero ideal que buscaba. De modo que, deteniéndose, me dijo con una sonrisa forzada la ineludible forzada sonrisa que campeó sobre toda aquella historia:

-Si quiere, entonces, baile este vals con su amor... -al parecer. No agregó una palabra más -repuse, pasando la mano por su cintura (pp. 119-129). 
Admitir por parte de María Elvira a todo trance de la presunta coacción, como la que se percibe en el personaje masculino, exterioriza lo que internamente no se aclara, no porque ello estriba en el olvido de una frase más o menos cliché dicha por la fémina, sino la evocación de eso que remite a los cambios que se plantean como las transformaciones que se dan a través de una sociedad donde conviene más la equidad y menos de los recaudos y privilegios propios para ciertos sectores económicos.

Reconocer el amor como abasto de la locura de Carlos Durán al cerrársele las puertas del acceso al coito, deviene la demencia experimentada al hacerse conforme pasa el tiempo, más difícil confiar en la estabilidad de un mundo en vías casi totales de interrelaciones y globalizaciones creadas por el capitalismo tardío y antes de que llegue la etapa del neoliberalismo estatal con sus tratados económicos desfavorecedores para los menos capaces de sobrevivir.

Si la preocupación del lector recayera en los artilugios del sentido, se estaría perdiendo como planteamos al principio de este trabajo, otros asuntos que se revisten de instancias tradicionales en cuanto al discurso y los enunciados de la vida social, construida por el tamiz y el derrotero del narrador en su contexto propio y además, como miembro de la estilización de vanguardia, interesada por transmitir ciertos cambios que se requieren, para que el sujeto sexual, se libere de las ataduras tradicionales.

Pero eso no es todo lo que podríamos concluir, el pretendido juego amoroso no es lo que se pudiera esperar, pues se nos desvía la atención a dos falsos principios implicados, primero la capacidad de resistir del masculino, segundo la resistencia vencida de la fémina, Nos hace pensar 
nuevamente en el viejo recurso del amor vencedor, cuando de lo que se trata, es de la declaración vedada de la inversión social por desgaste, no por revolución. Las nuevas ideas o ideales pos revolucionarias coincidentes con otras que se están dando, apuntan al desgaste de los modelos que se pensaron eran inamovibles antes de los siglos XVIII-XX. Ello da pie para el surgimiento de una nueva versión del héroe masculino y también femenino, el caudillo, pero esta vez de izquierda y revolucionario (a).

En realidad, yo concluyo que, la pareja conflictiva, desajustada y obviamente que se entrega en un abrazo amoroso, no llegan a nada antes de la utilización algo cursi del pos scriptum. La lectura semiótica nos impide afirmar que ellos en realidad se llegan a amar, solo es un gesto vacío de entendimiento y de tregua, pero la supuesta fusión, se ha comprobado, perpetúa el desacuerdo, el mismo que existe en la historia de los sectores humanos, encontrados y peleando por adquirir el centro en todo, la economía, el poder social y el económico, el dominio de las clases, el poder del acceso al coito, las instituciones, entre otras más.

Por eso, el análisis semiótico multimodal, duda de las estructuras mismas que validan con los modelos tradicionales y convencionales narrativos, que la ficción coincida con lo real, más bien nos ayuda a desmontar que eso real, se oculta a la vista de incautos lectores que confían más en lo que ven que en lo que está detrás de las esquinas donde termina la esquina de la cuadra, o escondido en las grietas de la pared. Eso sí que llena de terror, pues des-idealiza los atestados que componen esos mundos vacuos que, como esferas casi invisibles, nos dejan ver lo que contienen: lo horroroso, despiadado y depredador del ser humano, aunque este "ame". 
La forma semiótica artística-textual de decir y hacer lo in[debido]...

Por último, en virtud de que este espacio de la revista es reducido, quedan otras "modalidades" previstas que aumentarían el espectro enriqueciéndolo notablemente. Creo que para el espacio que brinda una tesis de grado, aventajaría mucho más las posibilidades de explayar otros asuntos que como dije, quedan en el tintero. 
Alvarado, O. G. (2010). El almohadón de plumas y las diferencias a partir del falo: una lectura de Horacio Quiroga. San José: Perro Azul.

\section{Referencias}

Bajtín, M. (1986). Problemas Literarios y Estéticos. La Habana: Arte y Literatura.

Bajtín, M. (1998). Estética de la creación verbal. D. F., México: Siglo XXI.

Gubern, R. (2005). Patologías de la imagen. Barcelona: Anagrama.

Lagarde, M. (1996). Género y Feminismo. Desarrollo Humano y Democracia. Madrid: horas y Horas.

Lotman, I. (1970). El arte como lenguaje. El arte entre otros sistemas semiológicos y Sobre la pluralidad de los códigos artísticos. En: $L a$ estructura del texto artístico, pp. 17-46.

Navarro, R. (2000). Enciclopedia de Escritores en Lengua Castellana. España: Planeta.

Quiroga, H. (2011). La Meningitis y su sombra. En: Cuentos de amor, de locura y de muerte. España: Ediciones Brontes, pp. 105-126.

Todorov, T. (1971). Literatura y significación. Barcelona: Planeta.

Van Dijk, T., Kress, G., Leite-García, R. y van Leeuwen, T. (2003). Semiótica Discursiva. En: El discurso como estructura y proceso, pp. 17-46. 
1. Considerados en orden de publicación estimaríamos los siguientes: 1957 José Enrique Etcheverry Horacio Quiroga y la creación artística 1967 Noe Jitrik Horacio Quiroga: una obra de experiencia y riesgo y también Horacio Quiroga; Ezequiel Martínez Estrada El hermano Quiroga. 1968 Emir Rodríguez Monegal El desterrado: vida y obra de Horacio Quiroga. 1973 Nicolás Bratosevich El estilo de Horacio Quiroga en sus cuentos. 1979 Ángel Flores Aproximaciones a Horacio Quiroga. Napoleón Baccino Ponce de León Horacio Quiroga: itinerarios. 2010. Oscar Gerardo Alvarado Vega El almohadón de plumas y las diferencias sexuales a partir del falo: una lectura en Horacio Quiroga, entre otros.

2. En relación a Lotman, se escogió La estructura del texto artístico y en cuanto a van Dijk El discurso como estructura y proceso elaborado también por Gunther Kress, Regina Leite-García y Theo van Leeuwen. Más datos se podrán encontrar en la bibliografía.

3. Doble percepción: real y virtual, ambas emparentadas; sincrónicas y diacrónicas.

4. La consideración de estos cambios, no es solo un juego caprichoso de carácter semántico, obtiene mayor riqueza dentro de la fenomenología que hace del sentido, un objeto activo, dinámico, sorpresivo para los estudios que se derivan de la comprensión del sentido, es decir, de la semiótica como ciencia.

5. La estimación comprende el desarrollo reflejo, es decir, el intercambio entre pares que alternan. 
6. Lotman utiliza los viejos cuños de las palabras emisor y receptor, solo que esta vez son según la explicación dada, otras comprensiones que rompen con las tradicionales.

7. El autor considera que lo literario es un producto social, pues los hablantes son tantos como hablas se puedan reconocer. La literatura, en plural y no quiero decir con esto la que se cataloga desde el criterio del establecimiento de las fronteras geográficas, son hechos que proceden de la diversidad cultural y que constituyen lo diverso, lo múltiple mucho antes que el filtro de la literatura, proceda a manosear dichas condiciones libres y haga con esa materia cultural lo que precede, es decir, la escritura.

8. Véase al respecto de la carta, el estudio de Tzvetan Todorov Literatura y significación.

9. El término y su sentido, es el que expresa el filósofo H. Marcuse en varios de sus escritos personales, aunque relacionados con la Escuela de Frankfurt y la Filosofía Social por estos desarrollada en el siglo pasado.

10. Según algunos las piensan naturales, biológicas y hasta culturales.

11. El tema de la semilla, encubre el del semen, la sémina esparcida por el mundo natural y atributo particular que obtiene el beneficiario. El subrayado es mío. 
12. Se resalta el asunto social en el entredicho que abren los puntos suspensivos, y el pronombre personal “ellos", los Funes, ricos, poderosos y además superiores al ingeniero.

13. De hecho, en cuanto a La Amortajada y el Gagliostro, originalmente fueron escrituras pensadas para el cine y como fracasaron como tales, se convirtieron en otro género de escritura vanguardista.

Recibido: 06-agosto-2015

Aceptado: 11-noviembre-2016

Todos los derechos reservados. Universidad de Costa Rica. Esta revista se encuentra licenciada con Creative Commons Reconocimiento-NoComercialSinObraDerivada 3.0 Costa Rica. (CC BY-NC-SA 3.0 CR)

Correo electrónico: humanidades@ucr.ac.cr Sitio web: http://revistas.ucr.ac.cr/index.php/humanidades 